\title{
Effects of Aqueous Extract of Onion (Allium cepa) on Blood Parameters in Adult Wistar Rats (Rattus novergicus)
}

\author{
Meraiyebu A.B ${ }^{1}$, Olaniyan O.T ${ }^{1}$, Anjorin Y.D ${ }^{2}$, Shekins $\mathrm{O}^{4}$, Dare B.J ${ }^{3}$, \\ Shafe M.O ${ }^{1}$ \\ ${ }^{I}$ Department of Physiology, Bingham University, Karu, Nasarawa, Nigeria. \\ ${ }^{2}$ Department of Physiology, University of Abuja, Abuja, Nigeria. \\ ${ }^{3}$ Department of Anatomy, Bingham University, Karu, Nasarawa Nigeria. \\ ${ }^{4}$ Department of Biochemistry, Bingham University, Karu, Nasarawa, Nigeria.
}

\begin{abstract}
Allium Cepa has been used in folk medicine for treatment of tumors and to relieve dropsy (heart failure related edema). This present study was conducted to determine the effects of the aqueous extract of onion (Allium cepa) on Blood parameters in Wistar rats. Eighteen (18) rats $(105-158 \mathrm{~g})$ were randomly selected into 3 groups of 6 animal $(n=6)$ each, Group A served as the control received $1 \mathrm{ml}$ of distilled water while Group B received $45 \mathrm{mg} / \mathrm{kg}$ body weight of onion juice and Group C received $20 \mathrm{mg} / \mathrm{kg}$ body weight of onion juice extracts for 21 days of experimental period. Animals were sacrificed by cervical dislocation 24 hours after the last administration and blood samples were collected via the retro-orbital route with the aid of a capillary tube, into an EDTA bottle for analysis. The result shows that the juice extracts at various doses significantly $(p<0.05)$ increase the total white blood cell counts, Lymphocyte count, Neutrophils count, also there was a significant $(p<0.05)$ increase in the red blood cell count in rats treated with onion juice. The packed cell volume of rats treated with onion extract were significantly $(p<0.05)$ increased. There was no significant $(p>0.05)$ increase in the Platelet count, Monocytes count, Eosinophil count, Basophil count of the rats in all groups. Allium cepa affect the amount of circulating blood cells thus promoting health benefits.
\end{abstract}

Keywords: Allium cepa, adult wistar rat, Blood parameters, Aqueous extract.

\section{Introduction}

During the past decade, traditional system of medicine has become a topic of global importance. Current estimates suggest that in many developing countries, a large proportion of the population relies heavily on traditional practitioners and medicinal plants to meet primary health care needs (WHO. 1999). Medicinal plants continue to provide valuable therapeutic agents, in both modern medicine and in traditional system to treat or prevent many diseases (Reaven et al; 1983). Onion has been used as food additive or supplement for many centuries. The onion plant is a bulbulous vegetable $1.2 \mathrm{~m}$ in height, with 4 to 6 hollow, cylindrical leaves. It is botanically referred to as Allium cepa. Its underground bulb, comprises of fleshy leaf sheaths forming a thin-skinned capsule, and varies greatly in size (2 to $20 \mathrm{~cm}$ ). Onion is also a popular folk remedy and is a staple food with a high content of flavonoids (Lanzotti; 2006). It contains $89 \%$ water, $1.5 \%$ protein, and vitamins $\mathrm{B}_{1}$, $\mathrm{B}_{2}, \mathrm{C}, \mathrm{K}$, and $\mathrm{E}$, along with calcium, potassium, magnesium, iron, phosphorus, zinc, sodium, selenium (Block, 2010), rich in flavonoids such as quercetin and sulfur compounds, such as allyl propyl disulphide that have perceived benefits to human health (Griffiths et al., 2002). In addition, onions are rich in sulfur containing compounds mainly in the form of cysteine derivatives, viz. S-alkyl cysteine sulfoxides which are decomposed by the enzyme allinase into a variety of volatile compounds such as thiosulfinates and polysulfides during extraction. These compounds possess anti-diabetic, antibiotic, hypocholesterolaemic, fibrinolytic, and various other biological effects. In addition to volatile substances in alliums, there are non-volatile sulfur-containing peptides and proteins which have been shown to have potential health benefits (Augusti, 1996). Allium containing substances have antibiotic effects and antibiotics should enable the proliferation of circulating white blood cells considering that white blood cells function to protect the body from teratogens (Augusti, 1996). Allium species, they have been implicated in the induction of haemolytic anaemia. They contain toxic components that may damage red blood cells and provoke haemolytic anaemia accompanied by Heinz bodies in erythrocytes of animals such as cattle, water buffalos, sheep, horses, dogs and cats (Banerjee and Maulik, 2002). Allium cepa juice has been found to exhibit antioxidant effect in alloxan induced diabetic rats; it also repaired hepatic and renal damage caused by the administered alloxan (El-Demerdash, et al., 2005). Epidemiological, clinical and laboratory studies have demonstrated the role of onion in cancer prevention (Galeone, et al., 2006) especially in relation to digestive tract cancers, including esophageal and stomach cancers (Berspalov et al., 2004). In the case of GI-related cancers, proposed mechanisms of action for the Allium species include an inhibition of Helicobacter pylori and other bacterial activity, as well as a general decrease in the endogenous production of carcinogenic N-nitroso compounds (Griffiths et al., 2002). The chemopreventive activity has 
been attributed to the ability to modulate the activity of several metabolising enzymes that activate (cytochrome P450s) or detoxify (glutathione S-transferases) carcinogens and inhibit the formation of DNA adducts in several target tissues (Hassan, 2004). The fact that allium cepa (onion) being widely used as food additive, due to its rich active constituents and antioxidant properties necessitated the need to investigate its effect on blood parameters.

\section{MATERIALS AND METHOD}

\section{Preparation of Extract (Allium Cepa)}

Fresh onion was obtained from Masaka market, Abuja - Keffi way- Nasarawa State and authenticated in the Department of Biology Bingham University, Karu, Nigeria. They were weighed and then blended with water. After which they were filtered into a conical flask using a filter paper and a funnel to produce a clear juice. The extracts were freshly prepared before administration and remnants were discarded.

\section{Experimental Animals}

A total of Eighteen (18) Adult Wistar rats of both sexes weighing between $105-158 \mathrm{~g}$ were used for this study. The animals were randomly divided into three (3) groups containing six (6) rats per group. The animals were housed and bred in the well-ventilated wooden cages with metal wiring and were allowed to acclimatize for Two (2) weeks. The animals were fed once daily with commercially formulated rat feed and water was given ad libitum. The research was carried out in accordance with the ethical rules on animals experimentation approved by the ethical committee of Bingham University.

\section{Extract Administration}

The extract was given by gavages orogastrically daily for period of 21 days, Animals in Group A were given $1 \mathrm{ml}$ of distilled water and serve as the control, Group B received $45 \mathrm{~g}$ of onion juice per kilogram body weight daily and Group $\mathrm{C}$ received $20 \mathrm{~g}$ of onion juice per kilogram body weight daily for 21 days of experimental period.

\section{Animal Sacrifice and Blood Collection}

Animals were sacrificed by cervical dislocation 24 hours after the last administration of the extract, and adequate blood was drawn from the rats through the retro-orbital route with the aid of a capillary tube, into an EDTA bottle to prevent coagulation.

\section{Analytical Procedure;}

The Blood samples were analysed for total white blood cell count, lymphocyte count, red blood cell count, monocytes count, eosinophil count, basophil count, platelet count and neutrophil count using haemocytometer method as described by Schalm et al. (1975) and Packed cell volume was estimated using the Laboratory method, microhaematocrit method as described by Schalm et al. (1975).

\section{Statistical Analysis;}

The values are recorded as mean \pm SEM at $\mathrm{p}<0.05$ significant different using student " $\mathrm{t}$ " test.

\section{RESULT AND DISCUSSION}

There was significant $(\mathrm{p}<0.05)$ increase in the lymphocyte count, red blood cell count in the treatment group when compared to the control as shown in Table I, the increase was more significant in the group treated with $45 \mathrm{~g} / \mathrm{kg}$ (lymphocyte count $67.92 \pm 2.95$, red blood cell count $5.67 \pm 0.38$ ) body weight of onion juice extract when compare with the group treated with $20 \mathrm{~g} / \mathrm{kg}$ (lymphocyte count $64.72 \pm 2.65$, red blood cell count $5.41 \pm 0.26)$ of the extract. Neutrophil and PCV show significant difference in the low dose group $(20 \mathrm{~g} / \mathrm{kg})$ when compared with the high dose treated animals. Conversely, Total white blood cell count Monocytes count, Eosinophil count, Basophil count, Platelet count were relatively lowered in the treatment group when compared to the control but the decrease was not statistically difference $(\mathrm{p}>0.05)$ as shown in Table I and II. 
Table I: Shows the effects of Allium cepa on the Total white blood cell counts, Lymphocyte count, Neutrophil count, Red blood cell count, Packed cell volume

\begin{tabular}{lccccc}
\hline & $\begin{array}{c}\text { Total White Blood } \\
\text { Cell } \\
\left(\times 10^{3} / \mu \mathrm{l}\right)\end{array}$ & $\begin{array}{c}\text { Lymphocyte } \\
\left(\mathrm{x} 10^{3} / \mu \mathrm{l}\right)\end{array}$ & $\begin{array}{c}\text { Neutrophil } \\
\left(\mathrm{x} 10^{3} / \mu \mathrm{l}\right)\end{array}$ & $\begin{array}{c}\text { RBCCount } \\
\left(\mathrm{x} 10^{3} / \mu \mathrm{l}\right)\end{array}$ & PCV\% \\
\hline CONTROL & $5.83 \pm 0.18$ & $63.65 \pm 0.36$ & $23.97 \pm 0.94$ & $5.25 \pm 0.19$ & $44.83 \pm 2.48$ \\
ONION LOW & $4.56 \pm 0.34$ & $64.72 \pm 2.65$ & $25.77 \pm 2.16^{*}$ & $5.41 \pm 0.26^{*}$ & $51.0 \pm 3.30^{*}$ \\
DOSE & & & & \\
ONION HIGH & $4.61 \pm 0.23$ & $67.92 \pm 2.95^{*}$ & $22.12 \pm 2.45$ & $5.67 \pm 0.38^{*}$ & $47.33 \pm 1.94^{*}$ \\
DOSE & & & & & \\
& & & & & \\
\hline $\begin{array}{l}\text { Values are Mean } \pm \text { S.E.M }(\mathrm{n}=6): * \text { indicate significant different when compared with the control } \\
(\mathrm{p}<0.05)\end{array}$
\end{tabular}

Table II: Shows the effects of Allium Cepa on the Monocytes count, Eosinophil count, Basophil count, Platelet count.

\begin{tabular}{lcccc}
\hline & $\begin{array}{l}\text { Monocytes } \\
\left(\mathrm{x} 10^{3} / \mu \mathrm{l}\right)\end{array}$ & $\begin{array}{c}\text { Eosinophil } \\
\left(\mathrm{x} 10^{3} / \mu \mathrm{l}\right)\end{array}$ & $\begin{array}{c}\text { Basophil } \\
\left(\mathrm{x} 10^{3} / \mu \mathrm{l}\right)\end{array}$ & $\begin{array}{l}\text { Platelet } \\
\left(\mathrm{x} 10^{3} / \mu \mathrm{l}\right)\end{array}$ \\
\hline CONTROL & $7.02 \pm 0.31$ & $4.4 \pm 0.41$ & $0.48 \pm 0.05$ & $445.83 \pm 21.15$ \\
$\begin{array}{l}\text { ONION LOW } \\
\text { DOSE }\end{array}$ & $5.52 \pm 0.42$ & $3.13 \pm 0.26$ & $0.88 \pm 0.43$ & $385 \pm 34.96$ \\
$\begin{array}{l}\text { ONION HIGH } \\
\text { DOSE }\end{array}$ & $6.28 \pm 0.25$ & $3.89 \pm 0.48$ & $1.82 \pm 0.61$ & $416.33 \pm 22.68$ \\
& & & &
\end{tabular}

\footnotetext{
Values are mean \pm S.E.M $(n=6)$
}

Allium containing substances have antibiotic effects and antibiotics should enable the proliferation of circulating white blood cells considering that white blood cells function to protect the body from teratogens according to Augusti, 1996, this was confirmed by the significant increase in the Lymphocytes count in the animal treated with onion juice extract as shown in Table I. Monocytes count was seen to insignificantly lower in the treated animals when compared with the control animals this might have resulted from Anti-microbial effects and Antioxidant effects of onion (Banerjee and Maulik. 2002). Microbial products can directly activate monocytes and this leads to production of pro-inflammatory and with some delay of anti-inflammatory cytokines. Typical cytokines produced by monocytes are TNF tumor necrosis factor, interleukin-1 and interleukin-12 (Swirski et al; 2009). Eosinophils demonstrated insignificant decrease in the onion treated animals when compared with the control animals. The decrease in the Eosinophils count in the treated animals demonstrate the antioxidant property of onion juice extract as the free radical agent generate production of more Eosinophil this is in agreement with (Rietz et al; 1995; Vazquez-Prieto et al; 2010). Basophils were also insignificant affected in the treated animals compared with the control animals. Recent studies in mice suggest that basophils may also regulate the behavior of $\mathrm{T}$ cells and mediate the magnitude of the secondary immune response (Nakanishi et al; 2010). Increase in the RBC count in the treated animals display the blood promoting action of the onion juice extract as revealed by Griffiths, et al. 2002, stated that; Onion is also a popular folk remedy, rich in flavonoids such as quercetin and sulfur compounds, such as allyl propyl disulphide that have perceived benefits to human health (Griffiths, et al., 2002). Conversely, Banerjee and Maulik, 2002 observed that Allium species, they have been implicated in the induction of haemolytic anaemia. They contain toxic components that may damage red blood cells and provoke haemolytic anaemia accompanied by Heinz bodies in erythrocytes of animals such as cattle, water buffalos, sheep, horses, dogs and cats (Banerjee and Maulik, 2002). 


\section{Conclusions}

Onion juice extract has been found to possess antibiotic action by increasing the Lymphocytes count which may enhance immune system and also found to lead to a high response of production of antibodies. Thus onion juice extracts demonstrated potential benefits to human health by causing increase in blood cells implicated in promoting good health and maintaining blood factors required for body defence.

\section{References}

[1]. Augusti KT. Therapeutic values of onion (Allium sativum L.) and garlic (Allium sativum L.) Indian Journal Experiment Biology (1996) 34: 634-40.

[2]. Banerjee SK, Maulik SK. Effect of garlic on cardiovascular disorders: a review. Nutritional Journal (2002) 1(1): 4.

[3]. Berspalov VG, Shcherbakov AM, Kalinovskii VP, Novik VI, Chepik OF, Aleksandrov VA,

[4]. Sobenin IA, Orekhov AN. Study of the antioxidant drug "Karinat" in patients with chronic atrophic gastritis Vopr Onkol. International Journal of phytotherapy (2004). 50 (1), 81-5. 66

[5]. Block, E. Garlic and Other Alliums: $1^{\text {st }}$ edition. The Lore and the Science. Royal Society of Chemistry (2010) ISBN 0-85404-1907 .

[6]. Campbell, Neil A. Biology (8th edition.). London: Pearson Education. (2008). ISBN 978-0-321-53616-7.

[7]. Cohen, Stephen. Burns, Richard C. Pathways of the Pulp, 8th Edition. St. Louis: Mosby, (2002) Inc.

[8]. El-Demerdash, F.M., Yousef, M.I., Abou El-Naga, N.I. Biochemical study on the hypoglycemic effects of onion and garlic in alloxan-induced diabetic rats. Food and Chemical Toxicology (2005) 43 (1), 57- 63.

[9]. Erich Sackmann, Biological Membranes Architecture and Function., Handbook of Biological Physics, (edited by R.Lipowsky and E.Sackmann,) (1995) volume.1, Elsevier.

[10]. Galeone C, Pelucchi C, Levi F, Negri E, Franceschi S, Talamini R, Giacosa A, La Vecchia C.

[11]. Onion and garlic use and human cancer. American Journal of Clinical Nutrition.; (2006) 84(5):1027-32.

[12]. Griffiths, G., Trueman, L., Crowther, T., Thomas, B. Onions: a global benefit to healthPhytotherapy Research (2002) 17 (7), 603615 .

[13]. Hassan HT. Ajoene (natural garlic compound): a new anti-leukaemia agent for AML Therapy. Leukaemia Research. (2004) 28 (7):667-71.

[14]. Lanzotti V. The analysis of onion and garlic. Journal of Chromatography A, (2006). 1112 (1-2, 3-22

[15]. Nakanishi, Kenji "Basophils as APC in Th2 response in allergic inflammation and parasite infection".CurrentOpinionin Immunology (2010) 22 (6): 814-820.

[16]. Reaven, E., Wright, D., Mondon, C.E., Solomon, R., Ho, H., Reaven, G.M. Effect of age and diet on insulin secretion and insulin action in the rat. Diabetes. (1983) 32, 175-180.

[17]. Rietz B, Belagyi J, Torok B, Jacob R. The radical scavenging ability of garlic examined in various models. Bolletino Chimico Farmaceutico, (1995). 134: 69-76.

[18]. Schalm, O.W ., Jain N.C and Caroll, E.J: Textbook of Veterinary Haematology, $2^{\text {nd }}$ Edition, Published by Lea and Febiger, Philadelphia, (1975) Pp. 129-250.

[19]. Swirski FK, Nahrendorf M, Etzrodt M, Wildgruber M, Cortez-Retamozo V, Panizzi P, Figueiredo J-L, Kohler RH, Chudnovskiy A, Waterman P, Aikawa E, Mempel TR, Libby P, Weissleder R, Pittet MJ. Identification of Splenic Reservoir Monocytes and Their Deployment to Inflammatory Sites. Science, (2009). 325: 612-616.

[20]. Vazquez-Prieto M.A, Gonzalez R.E, Renna N.F, Galmarini C.R, Miatello R.M. Aqueous garlic extracts prevent oxidative stress and vascular remodelling in an experimental model of metabolic syndrome. J Agric Food Chem. (2010) 9; 58 (11): 6630-5.

[21]. Voehringer D. Trends in Parasitology. (2009) Volume 25. Issue 12. 551-556

[22]. WHO monographs on selected medicinal plants (1999) Volume I, WHO, Geneva

[23]. Young, Barbara; Lowe, Joseph O'connell; Stevens, Alan; Heath, John W. Wheater's Functional Histology (5 edition.). Elsevier Limited. (2006) ISBN 0-443-06850-X. 